https://helda.helsinki.fi

\title{
NSE concentrations and haemolysis after cardiac arrest
}

\author{
Jakkula, Pekka
}

2019-05

Jakkula , P , Skrifvars, M B , Pettilä , V , Hästbacka , J \& Reinikainen , M 2019 , ' NSE

concentrations and haemolysis after cardiac arrest ' , Intensive Care Medicine , vol. 45 , no.

5 , pp. 741-742 . https://doi.org/10.1007/s00134-019-05547-8

http://hdl.handle.net/10138/303404

https://doi.org/10.1007/s00134-019-05547-8

publishedVersion

Downloaded from Helda, University of Helsinki institutional repository.

This is an electronic reprint of the original article.

This reprint may differ from the original in pagination and typographic detail.

Please cite the original version. 


\title{
LETTER
}

\section{NSE concentrations and haemolysis after cardiac arrest}

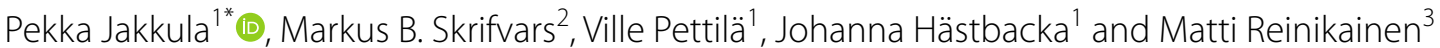

(c) 2019 Springer-Verlag GmbH Germany, part of Springer Nature

\section{Dear Editor,}

We read with great interest the editorial by Nielsen et al. [1] regarding our recent publications in Intensive Care Medicine $[2,3]$. We thank the authors for their opinions and agree with most of the expressed views. However, we feel that the critique against the neuron-specific enolase (NSE) analyses and our definition of haemolysis is not justified.

Briefly, we obtained 463 serum samples for the analyses of NSE concentrations at ICU admission and 24, 48 and $72 \mathrm{~h}$ after cardiac arrest. In seven samples (1.5\%), the Roche haemolysis index was over 50 (corresponding to $500 \mathrm{mg}$ of free haemoglobin per litre). We excluded these samples from the analyses. In the samples taken at the Danish centre $(n=26)$, the NSE concentration was analysed immediately and haemolysis was not assessed.

Of the remaining 430 samples, there was detectable haemolysis (haemolysis index $\geq 10$ ) in 150 samples (34.9\%). The mean haemolysis index \pm standard deviation in these samples was $19.0 \pm 9$. The amount of these moderately haemolytic samples was comparable in all the intervention groups. Notably, our main findings remained unchanged after exclusion of all samples with detectable haemolysis: the study interventions had no impact on the NSE concentrations (Table 1). Accordingly, we conclude that our results are not biased because of the impact of haemolysis on NSE concentrations.

Nielsen et al. claimed that our original threshold for defining significant haemolysis, $500 \mathrm{mg}$ of free haemoglobin per litre, was too high. However, the very same threshold has been used in previous studies [4], including the TTM trial. Furthermore, in other studies using NSE as the primary outcome, haemolysis was not assessed at all [5].

Table 1 Median (inter-quartile range) serum neuron-specific enolase concentrations at $48 \mathrm{~h}$ after cardiac arrest with all samples with detectable haemolysis (Roche haemolysis index $\geq 10$ ) excluded

\begin{tabular}{llc}
\hline Intervention group & NSE $(\mu \mathrm{g} / \mathrm{l})$ & $p$ value \\
\hline Low-normal $\mathrm{PaCO}_{2}$ & $17.3(13.3-25.0)$ & 0.156 \\
High-normal $\mathrm{PaCO}_{2}$ & $21.8(13.8-34.9)$ & \\
Normoxia & $18.4(13.4-25.2)$ & 0.232 \\
Moderate hyperoxia & $18.8(13.6-34.9)$ & \\
Low-normal MAP & $19.1(13.9-33.8)$ & 0.433 \\
High-normal MAP & $17.3(13.5-30.3)$ & \\
\hline
\end{tabular}

NSE neuron-specific enolase, $\mathrm{PaCO} 2$ arterial carbon dioxide tension, MAP mean arterial pressure 


\section{Author details}

${ }^{1}$ Department of Anaesthesiology, Intensive Care and Pain Medicine, Helsinki University Hospital, University of Helsinki, Helsinki, Finland. ${ }^{2}$ Department of Anaesthesiology, Intensive Care and Pain Medicine and Department of Emergency Medicine and Services, Helsinki University Hospital, University of Helsinki, Helsinki, Finland. ${ }^{3}$ Department of Anaesthesiology and Intensive Care, Kuopio University Hospital, University of Eastern Finland, Kuopio, Finland.

\section{Compliance with Ethical Standards}

\section{Conflicts of interest}

None.

\section{Ethical approval}

An approval by an ethics committee was not applicable.

\section{Publisher's Note}

Springer Nature remains neutral with regard to jurisdictional claims in published maps and institutional affiliations.

\section{References}

1. Nielsen N, Cariou A, Hassager C (2018) Physiological interventions in cardiac arrest: passing the pilot phase. Intensive Care Med. https://doi. org/10.1007/s00134-018-5492-2

2. Jakkula P, Pettilä V, Skrifvars MB et al (2018) Targeting low-normal or high-normal mean arterial pressure after cardiac arrest and resuscitation: a randomised pilot trial. Intensive Care Med 44:2091-2101. https://doi. org/10.1007/s00134-018-5446-8

3. Jakkula P, Reinikainen M, Hästbacka J et al (2018) Targeting two different levels of both arterial carbon dioxide and arterial oxygen after cardiac arrest and resuscitation: a randomised pilot trial. Intensive Care Med 44:2112-2121. https://doi.org/10.1007/s00134-018-5453-9

4. Stammet $\mathrm{P}$, Collignon $\mathrm{O}$, Hassager C et al (2015) Neuron-specific enolase as a predictor of death or poor neurological outcome after out-ofhospital cardiac arrest and targeted temperature management at $33^{\circ} \mathrm{C}$ and $36^{\circ} \mathrm{C}$. J Am Coll Cardiol 65:2104-2114. https://doi.org/10.1016/j. jacc.2015.03.538

5. Eastwood GM, Schneider AG, Suzuki S et al (2016) Targeted therapeutic mild hypercapnia after cardiac arrest: a phase II multi-centre randomised controlled trial (the CCC trial). Resuscitation 104:83-90. https://doi. org/10.1016/j.resuscitation.2016.03.023

Accepted: 24 January 2019

Published online: 13 February 2019 